Katarzyna Zamorska

Uniwersytet Wrocławski

\title{
Rola nauk społecznych w projektach programów i reform społecznych
}

DOI: $10.19195 / 1643-0328.23 .5$

Słowa kluczowe: nauki społeczne, polityka społeczna, prawa nauk społecznych, reforma

\section{Wprowadzenie}

Rozważania zawarte w tym artykule, do których chcę także zachęcić czytelnika, poruszają dwa odmienne aspekty podejmowanego zagadnienia. Pierwszy z nich nawiązuje do roli nauk społecznych jako zaplecza intelektualnego dla programów reform społecznych. Akcentując ich znaczenie, wszak reforma oznacza "szczególny rodzaj poprawy”", wskażę także na pewne związane z tym problemy. Ponieważ jednak liczba czynników, które wpływają na programy i reformy społeczne, jest bardzo duża, a ich różnorodność nie pozwala uwzględnić ich wszystkich $\mathrm{w}$ krótkim ujęciu, przedstawię tylko niektóre, ale - jak sądzę - wystarczające dla naszych potrzeb przykłady.

Drugi aspekt, który omawiam, ukazuje konsekwencje określonego definiowania reformy i przypisywania jej wysokiej (lub nie) pozycji w skali wartości działań społecznych oraz praktykę jej realizacji. Pojawia się tu pytanie o charakter reform w Polsce, począwszy od lat 90 . XX w. po okres obecny. Czy reformy oznaczały gruntowną zmianę, a więc miały charakter rewolucyjny, czy też ewolucyjny, polegający na długotrwałym przekształcaniu elementów systemu politycznego?

Na początku odnotuję jednak pewne zastrzeżenia w dyskusji. Podjęcie i realizacja decyzji, których konsekwencją są określone działania w ramach polityki społecznej, w dużej mierze zależą od tego, jak są zdefiniowane i w jaki sposób układają się relacje między naukami społecznymi, polityką a społeczeństwem. W ujęciu optymalnym dla naszego tu użytku mogłoby to przybrać następujący schemat: nauki społeczne reprezentowane są przez badaczy, którzy dostarczają wiedzy, umożliwiającej podjęcie określonych decyzji, a także pozwalają przewidzieć ich konsekwencje. Same nauki społeczne tak definiują swoją rolę i miejsce w społeczeństwie. Wspomagani przez zaplecze naukowe politycy,

1 A. Heywood, Teoria polityki. Wprowadzenie, Warszawa 2009, s. 341. 
którzy są odpowiedzialni za realizację zadań i celów polityki społecznej, przygotowują perspektywiczne programy i projekty reform społecznych. Zadaniem zarówno nauk społecznych, jak i polityki jest pogłębianie dialogu społecznego, dzięki któremu proponowane rozwiązania dotrą w zrozumiałej i akceptowalnej formie do społeczeństwa. Ostatecznie to ono jest adresatem i beneficjentem wszelkich reform społecznych, ale ponosi także konsekwencje w razie ich niepowodzenia. Wydaje się, że najbardziej wrażliwym elementem tego modelu jest społeczeństwo. Okazuje się jednak, że także te elementy, które wydają się łatwo poddawać kontroli i korekcie (nauka, polityka), mogą podlegać rozmaitym wpływom. Od tego zatem, jak przebiega współpraca i komunikacja pomiędzy światem nauki, politykami i społeczeństwem, może zależeć powodzenie reform i programów społecznych.

Przedmiotem artykułu jest zatem kilka problemów związanych z zastosowaniem wiedzy z obszaru nauk społecznych do programów i projektów reform społecznych. Rozpocznę od przedstawienia okoliczności, w jakich nastąpiło stopniowe wyodrębnianie się nauk społecznych. Przyjrzę się także niektórym kontrowersjom, które dotyczą zagadnienia istnienia praw w naukach społecznych i wynikających stąd trudności, stawiających pod znakiem zapytania ich przydatność w tworzeniu obiektywnej wiedzy dotyczącej rynku, państwa i społeczeństwa obywatelskiego. Podam też przykłady zastosowania nauk społecznych do uzasadnienia reform i programów społecznych. Następnie odniosę się do polskich doświadczeń reformatorskich, wynikających ze zmiany paradygmatu polityki społecznej w latach 90. ubiegłego wieku. Na koniec dokonam podsumowania.

\section{Początki i rozwój nauk społecznych}

Rozróżnienie nauk na przyrodnicze i „o duchu”, które zajmują się kulturą i jej wytworami, a zatem są naukami humanistycznymi, pojawiło się w XIX w. za sprawą m.in. Wilhelma Diltheya (1833-1911). O ile te pierwsze dążą do wyjaśnienia zjawisk poprzez odniesienie ich do ogólnych praw, o tyle drugie czynią wysiłek, by zrozumieć zjawiska w ich wyjątkowości. Nadanie jakiemuś rodzajowi wiedzy o społeczeństwie statusu nauki oznacza, że „pod ważnymi względami jest ona porównywalna z naukami przyrodniczymi" $^{2}$. Dilthey zakwalifikował do nich historię, ekonomię polityczną, nauki o prawie i państwie, religioznawstwo, literaturoznawstwo, teorię sztuk plastycznych i muzyki, światopoglądy i systemy filozoficzne oraz psychologię․ Sukcesywnie podział ten podlegał jeszcze większemu uszczegółowieniu i - obok nauk przyrodniczych oraz humanistycznych - zaczęto wyodrębniać również nauki społeczne. Ustalenie miejsca badań nad rzeczywistością społeczną było - jak zauważa Immanuel Wallerstein - najtrudniejszą kwestią, dlatego „początkowo nauki społeczne lokowały się po środku - po-

\footnotetext{
2 Słownik socjologii i nauk społecznych, red. G. Marshall, red. naukowa wyd. polskiego M. Tabin, Warszawa 2005, s. 206.

3 W. Dilthey, Budowa świata historycznego w naukach humanistycznych, Gdańsk 2004, s. 20.
} 
między »czystymi naukami« $\mathrm{i}$ »naukami humanistycznymi «"4. Nie było to najtrafniejsze rozwiązanie, ponieważ

badacze społeczni nigdy nie wypracowali odrębnej, trzeciej drogi gromadzenia wiedzy, podzielili się natomiast na tych, którym bliżej było do "naukowego" lub „scjentystycznego" spojrzenia na nauki społeczne, i tych, którym bliżej było do ujęcia "humanistycznego" ${ }^{\text {. }}$.

Według tych, którzy zajmują się specyfiką przedmiotowych zainteresowań naukowych, za najstarsza naukę społeczną uznaje się historię. Problem polegał jednak na tym, że dotyczy ona przeszłości, a zatem nie udziela odpowiedzi na pytania dotyczące aktualnej sytuacji w poszczególnych państwach. W tej sytuacji kwestią czasu było pojawienie się nowych dyscyplin, które uwzględniałyby potrzeby artykułowane zarówno przez badaczy społecznych, jak i polityków. I jedni, i drudzy dążyli do posiadania większej wiedzy na temat czasów, w jakich przyszło im żyć. Z czasem pozyskały samoświadomość ekonomia, nauki polityczne i socjologia, a do każdej przypisana była inna sfera. Były to - odpowiednio - rynek, państwo i społeczeństwo obywatelskie ${ }^{6}$. Wysoką rangę tych pierwszych podkreślał John Maynard Keynes (1883-1946), twierdząc, że „idee głoszone przez ekonomistów oraz myślicieli politycznych, bez względu na to, czy są słuszne, czy błędne, mają większą siłę niż powszechnie się przypuszcza. W rzeczywistości to one właśnie rządzą światem”7. Z kolei Max Weber (1864-1920) definiował socjologię jako naukę, „która stara się zrozumieć na drodze interpretacji działania społeczne, a dzięki temu przyczynowo wyjaśniać ich przebieg i skutki" ${ }^{\text {. W }}$ toku późniejszej ewolucji nauk społecznych wyłoniły się m.in. antropologia, pedagogika, prawo, psychologia oraz zarządzanie.

Warto przy okazji zauważyć, że polski ustawodawca w $2011 \mathrm{r}$. w ramach obszaru nauk społecznych wyróżnił trzy dziedziny: nauk społecznych (nauki o bezpieczeństwie, nauki o obronności, nauki o mediach, nauki o polityce, nauki o polityce publicznej, nauki o poznaniu i komunikacji społecznej, pedagogika, psychologia, socjologia), nauk ekonomicznych (ekonomia, finanse, nauki o zarządzaniu, towaroznawstwo) oraz nauk prawnych (nauki o administracji, prawo, prawo kanoniczne) ${ }^{9}$. Na marginesie mówiąc, dyskusyjne w dalszym ciągu pozostaje, czy nauki humanistyczne i nauki społeczne należy traktować odrębnie ${ }^{10}$. Wszak wszystkie one badają wytwory świadomej i celowej działalności człowieka. Cechuje je ogromna różnorodność tak koncepcyjna, jak i metodologiczna. Jest to efekt wielości różnorodnych prądów, szkół oraz doktryn, ukształtowanych

${ }^{4}$ I. Wallerstein, Analiza systemów-światów. Wprowadzenie, Warszawa 2007, s. 17. Należy zauważyć, że sam Wallerstein, na którego opis nauk społecznych się tu powołuję, krytykuje podział nauk rodem z XIX w. na trzy suwerenne dyscypliny: ekonomię, politykę i socjologię.

5 Ibidem, s. 16, 17.

6 Ibidem, s. 19.

7 J.M. Keynes, Ogólna teoria zatrudnienia, procentu i pieniądza, Warszawa 2003, s. 350.

8 M. Weber, Gospodarka społeczna, t. 1. Kategorie socjologiczne, Warszawa 2002, s. 6.

9 Por. Rozporządzenie Ministra Nauki i Szkolnictwa Wyższego z 8 sierpnia 2011 r. w sprawie obszarów wiedzy, dziedzin nauki i sztuki oraz dyscyplin naukowych i artystycznych (Dz.U. z dnia 30 sierpnia 2011 r.).

10 Według autorów Słownika socjologii i nauk społecznych (op. cit., s. 206) „granice dyscyplin nie zawsze są jasno określone": psychologia przynależy raczej do nauk przyrodniczych, a nie społecznych. Z kolei ekonomia bezsprzecznie ma status nauk społecznych. Jednak już „status socjologii, psychologii społecznej, nauk politycznych i geografii rodzi większe problemy". 
na bazie odmiennych podejść filozoficznych i światopoglądowych, co nie pozostaje bez wpływu na przygotowywane projekty programów i reform społecznych. Dobrze to ilustruje przykład zachodnioeuropejskiego państwa opiekuńczego (welfare state). Największy jego rozwój przypadał na trzydzieści powojennych lat (między 1945 a 1975 r. - tzw. złotych trzydzieści lat dobrobytu) i wynikał z tragicznego doświadczenia XX-wiecznej Europy. Ideę państwa opiekuńczego trzeba było intelektualnie i analitycznie przemyśleć oraz zrozumieć, by dostrzec sens w budowie społeczeństwa, w którym jest (a przynajmniej miało być) miejsce dla każdego. Dyskusja w obrębie trzech doktryn — liberalnej, konserwatywnej i socjaldemokratycznej - przyczyniła się w konsekwencji do dyskusji na temat takich zagadnień, jak rola państwa i rynku w rozwiązywaniu problemów społecznych, kwestia równości, wolności (także w sensie pozytywnym) i sprawiedliwości społecznej. Warto też pamiętać, że zwiększanie szans kobiet na rynku pracy, zapewnienie opieki zdrowotnej czy wysunięcie, szczególnie w latach 80. XX w., na plan pierwszy debaty politycznej praw dziecka nie odbyłyby się bez rozwoju nauk społecznych.

Nauki społeczne ${ }^{11}$ pozwalają bowiem zrozumieć skomplikowane procesy społeczne. Dostarczają teorii, wyników badań, danych oraz ekspertyz niemal na każdy temat. Umożliwiają one interpretację i zrozumienie zarówno otaczającej nas rzeczywistości, jak i konkretnych zachowań ludzi, którzy w niej funkcjonują. Oczywiście, nie ma gwarancji, że zostaną w pełni wykorzystane, np. przy tworzeniu programów społecznych.

Wątpliwości w przypadku użyteczności nauk społecznych mogą sprowadzać się do kwestii metodologicznych i ich obiektywizmu. Przykładowo, przedstawiciele kierunku nauki, jakim jest antynaturalizm, utrzymują, że metoda badań w naukach społecznych i humanistycznych jest odmienna od metod, które są stosowane - za pośrednictwem nauk ścisłych - na gruncie nauk przyrodniczych. Konsekwencją takiej postawy jest przekonanie, że nauki społeczne nie generują praw, gdyż nie istnieją obiektywne prawidłowości społeczeństwa, które mogłyby te prawa odzwierciedlać. Właściwy wzorzec stanowią nauki przyrodnicze. Różni teoretycy rozmaicie zatem pojmowali status nauk społecznych i praw nimi rządzących. Według wspomnianego już Webera celem badacza nie jest odkrycie jakichś uniwersalnych praw społeczeństwa. Zadanie uczonego w naukach społecznych sprowadza się, zgodnie z jego wcześniej przytoczonym stanowiskiem, do rozumienia indywidualnych zdarzeń i wyjaśniania na ich podstawie sensu, jaki przypisują im jednostki. Zatem prawa w naukach społecznych — nawet gdyby je znaleźć - nie byłyby przydatne.

Na przeciwnym biegunie mamy z kolei pogląd, że można osiągnąć obiektywną wiedzę dotyczącą rynku, państwa i społeczeństwa obywatelskiego, gdyż rządzą się one prawami, „które można odkryć dzięki analizie empirycznej oraz indukcyjnym uogólnieniom”12. Jako przykład takich praw wskazuje się prawo podaży i popytu czy prawo wzrostu przestępczości wraz ze wzrostem poziomu bezrobocia. W literaturze przedmiotu można

11 Wspomniane procesy stają się zrozumiałe także dzięki naukom humanistycznym, bo przecież ważny głos, np. w sprawie sprawiedliwości społecznej, która stanowi o racji bytu choćby polityki społecznej, należy m.in. do filozofii społecznej.

12 I. Wallerstein, op. cit., s. 19. 
spotkać się z hipotezą, wedle której bezrobocie (zwłaszcza długotrwałe) przyczynia się do wzrostu zachowań o charakterze kryminogennym. Innymi słowy, wzrost bezrobocia wpływa zasadniczo na dochody tych, którzy stracili pracę, a spadek dochodów lub w ogóle ich brak prowadzi do wzrostu bezrobocia. Pozbawienie możliwości legalnego zarobkowania stwarza trudną sytuację ekonomiczną, która popycha do przestępstwa. Chodzi tu o oddziaływanie bezrobocia na zachowania sprzeczne z prawem dotkniętych nim ludzi. Jest to istotny problem z punktu widzenia polityki społecznej, gdyż następstwem bezrobocia i przestępczości jest trwałe, a coraz częściej dziedziczone, wykluczenie społeczne ${ }^{13}$. Jednak takie decyzje wśród poszczególnych ludzi mogą być także - czego dowiódł Gary S. Becker, proponując podejście ekonomiczne do przestępczości - wynikiem przemyślanej analizy zysków i strat ${ }^{14}$. Zatem liczba czynników, które wpływają na działania ludzkie, dokonywane wybory i interpretację faktów, jest bardzo duża.

Zgodnie $\mathrm{z}$ innym jeszcze stanowiskiem prawa społeczne mogą istnieć, ale jedynie w konkretnych warunkach społecznych i podporządkowane są regułom i normom kulturowym, które uznaje społeczeństwo ${ }^{15}$. Uzasadnienie opiera się na spostrzeżeniu, że interesująca nas tu dziedzina naukowa, będąca częścią nauki instytucjonalnej, jest wpisana w makrostrukturalny ład systemu społecznego i jest z nim powiązana funkcjonalnie na wiele sposobów. Tym samym włącza ona wartości, cele i dominujący typ racjonalności społecznej we wszystkie metodologicznie legitymizowane procedury ${ }^{16}$. W tym sensie prawa nauk społecznych nie mają charakteru uniwersalnego, tak jak prawa przyrody. Ujmując rzecz jeszcze inaczej, dzięki naukom społecznym zdolni jesteśmy wyjaśnić tylko to, co już miało miejsce. Potwierdzać to może przykład ostatniego kryzysu gospodarczego, który nie został przewidziany przez ekonomistów, natomiast jest dogłębnie analizowany post factum.

\section{Wiedza a działania w obszarze polityki społecznej}

Dlaczego reformy w jednych państwach się udają, a zastosowanie tych samych rozwiązań w innych kończy się niepowodzeniem? Dlaczego jedne społeczeństwa są przychylnie nastawione do przeprowadzanych zmian w programach społecznych, a inne nie? Czy jeśli zakłada się istnienie ogólnych praw, które rządzą zachowaniem społecznym, to nie oznacza to, że będą one prawdziwe w różnych miejscach i czasach? Wreszcie, w jaki sposób wesprzeć politykę społeczną, rozumianą jako działalność praktyczna, wiedzą z zakresu nauk społecznych jako wiedzą użyteczną w tym sensie, że pozwala ona na wybór najbardziej optymalnego $\mathrm{w}$ danym czasie rozwiązania?

13 A. Kiersztyn, Czy bieda czyni złodzieja? Związki między bezrobociem, ubóstwem a przestępczościa, Warszawa 2008, s. 85.

${ }^{14}$ G.S. Becker, Crime and punishment: An economic approach, www.nber.org/chapters/c3625.pdf (dostęp: 23 października 2017).

15 A. Grobler, Metodologia nauk, Kraków 2006, s. 230.

16 M. Malewski, Teorie andragogiczne - metodologia teoretyczności dyscypliny naukowej, Wrocław 1998, s. 165. 
Odpowiedzi na te m.in. pytania próbują udzielać, zgodnie z zastaną aktualnie wiedzą, właśnie przedstawiciele nauk społecznych. Dlatego, jak zauważyli Ted Benton i Ian Craib, nauki społeczne „mogły oczekiwać, że zostaną potraktowane poważnie przez działaczy sceny politycznej” ${ }^{17}$. Dostarczają bowiem - poprzez budowanie teorii, gromadzenie licznych danych - wiedzy na temat rozmaitych aspektów życia społecznego, takich jak bezrobocie, ubóstwo, wzorce zawierania małżeństw, procesy demograficzne, postawy i akceptowane wartości, aspiracje edukacyjne społeczeństwa itp. Można zatem założyć, że analiza tego całościowego materiału pozwala na wyciągnięcie wniosków ważnych w kreowaniu tak bieżącej, jak przyszłej polityki oraz przełożenie ich na konkretne działania.

Ilustracją niech będą dwa przykłady. Pierwszy dotyczy sytuacji demograficznej. Można ją opisać poprzez stan liczebny ludności, przyrost naturalny, migracje, strukturę płci, wieku czy wykształcenia. Odpowiedzi na pytanie, dlaczego procesy demograficzne przebiegają tak, a nie inaczej, należy jednak szukać nie tylko u demografów, ale także u ekonomistów, którzy mogą wyjaśnić np. relacje zachodzące między poziomem dzietności a bezrobociem. Socjolodzy z kolei mogą wskazać na zmianę stylu życia, w którym to, co indywidualne, jest wyżej cenione niż to, co wspólnotowe. Niski przyrost naturalny przyczynił się w większości państw Europy do zmiany struktury wiekowej społeczeństwa. Klasyczna piramida wiekowa opiera się na mocnych podstawach, którą stanowią ludzie młodzi. Wraz z wiekiem zwęża się ona ku górze. Obecnie mamy do czynienia z sytuacją, gdzie ta podstawa zaczyna być coraz mniejsza, a przybywa ludzi w wieku poprodukcyjnym. Z punktu widzenia polityki społecznej jest to zagadnienie, które sprowadza się do polityki mieszkaniowej (inne wymagania mieszkaniowe), opieki zdrowotnej (wzrost zapotrzebowania), przewagi osób w wieku poprodukcyjnym (problem emerytur). W tej sytuacji większość rządów krajów, w których społeczeństwo się starzeje, podnosi wiek emerytalny. Czyni się tak zarówno ze względu na stan obecny, jak i przyszły budżetu. Społeczeństwo, którego takie rozwiązanie dotyczy, nie zawsze musi być przekonane co do jego słuszności. I tu rolę do odegrania mają decydenci, stojący za reformami, oraz badacze, reprezentujący nauki społeczne, którzy w odpowiedni sposób powinni wyjaśnić konieczność wprowadzanych zmian.

Drugi przykład jest bardziej szczegółowy i pokazuje, jakie można — uwzględniając konkretną sytuację - proponować rozwiązania. „Według statystyk może okazywać się, że zachowania przestępcze nieletnich są powszechniejsze wśród dzieci z rozbitych rodzin. Nie jest to uniwersalne prawo, lecz generalizacja statystyczna"18. Owa generalizacja może być wykorzystana do przekonania polityków, odpowiedzialnych za kreowanie polityki społecznej, a także opinii publicznej, że konieczne jest podjęcie działań w celu zmniejszenia wskaźników przestępczości wśród nieletnich. Może się okazać, że przestępczość nieletnich występuje częściej w rodzinach, w których doszło do rozwodu rodziców. Wtedy wyjaśnienie naukowe mogłoby wesprzeć działania na rzecz redukcji wskaźników rozwodów. Bardziej subtelne metody analityczne wykażą,

17 T. Beton, I. Craib, Filozofia nauk społecznych, Wrocław 2003, s. 37.

18 Ibidem. 
że zależności te są o wiele bardziej złożone, gdyż mogą na nie nakładać się jeszcze inne, dodatkowe powody, np. poziom bezrobocia i jego charakter (krótko- czy długotrwały), obowiązujące wartości i wynikająca zeń postawa wobec rozwodów. Tego rodzaju wiedza będzie podstawą do podjęcia określonych w danej chwili działań. Może ona polegać albo na zmniejszaniu wskaźników rozwodów, albo na reagowaniu na skutki bezrobocia, albo na dążeniu do kulturowej zmiany „na rzecz bardziej liberalnych wartości społecznych" ${ }^{19}$. Te działania nie wykluczają się zresztą nawzajem i mogą być prowadzone równolegle.

Problem może stwarzać sposób wykorzystania wielości rozmaitych teorii, informacji, danych, ekspertyz przez decydentów. Czy np. konkretne działania w ramach poszczególnych polityk społecznych są oparte na wiedzy, czy raczej wiedza posłużyła do tego, by uzasadnić politykę? Jak zauważa Tadeusz Klementewicz, „wbrew zawodowej ideologii to ze środowiska naukowego rekrutuje się »klasa sług «, których misją jest naturalizowanie Systemu. Obecnie to głównie bankowi ekonomiści oraz ich katedralni nauczyciele"20. Cytat ten m.in. dowodzi, że występuje problem w relacji między naukami społecznymi a decyzjami politycznymi.

Zależności te badali Władysław Markiewicz i Witold Morawski, którzy wyróżnili pięć typów stanowisk w relacjach badaczy i przedstawicieli władzy. Pierwsze trzy odnoszą się co prawda do czasów sprzed transformacji systemowej, jednak nie jest wykluczone, że mogą one być obecne także dzisiaj. Są to: bezwarunkowe poparcie badaczy wobec władzy, czego nie trzeba wyjaśniać, oraz orientacja pozytywistyczna ${ }^{21}$. Trzecia orientacja określona została jako reformistyczna. Przy czym to ostatnie stanowisko charakterystyczne jest dla okresu po $1981 \mathrm{r}$. i polegało na współpracy z ówczesną władzą. Celem tej współpracy było kształtowanie oświeconej elity. Kolejne stanowisko nosi charakter naukowo-administracyjny i odnosi się do badaczy, którzy przeszli na stronę decydentów. Ostatnie stanowisko to pośrednie doradztwo poprzez kształtowanie opinii publicznej ${ }^{22}$.

Ważnym zatem czynnikiem, mającym wpływ na podejmowane decyzje w zakresie programów i reform społecznych, są sami badacze, którzy mogą różnić się między sobą poglądami, jak też doświadczeniem. Należy brać to pod uwagę, zwłaszcza że to przedstawiciele nauk społecznych legitymizują panujący ład społeczny, udostępniając odpowiedzialnym za realizację polityki społecznej fakty i podając ich gotowe interpretacje.

\section{Ibidem.}

20 T. Klementewicz, Kompradorzy znad Wisły, „Le Monde diplomatique” nr 134, 2017, http://monde-diplomatique.pl/LMD134/index.php?id=4_2(dostęp: 3 lipca 2017).

21 Pozytywiści optowali za koncepcją wiedzy w naukach społecznych jako wiedzy użytecznej w tym sensie, że można ją wprząc w proces polityki społecznej traktowanej jako inżynieria społeczna.

22 Zob. W. Markiewicz, W. Morawski, The Influence of Social Sciences on Political Decisions in Poland, [w:] Social Sciences and Modern States: National Experiences and Theoretical Crossroads, red. P. Wagner et al., Cambridge 1991, s. 207-214. 


\section{Reformy społeczne}

Wbrew etymologii wyraz „reforma”, który w najwcześniejszym znaczeniu był równoznaczny z odtwarzaniem przeszłości ${ }^{23}$, oznacza robienie czegoś nowego: tworzenie nowych form, w przeciwieństwie do starych. W tym znaczeniu jest to działanie o charakterze pozytywnym i polega na przeobrażaniu osoby, instytucji lub systemu - reformy „mogą pozbawić je cech niepożądanych bez wpływania na ich zasadniczy charakter. W gruncie rzeczy pozostają tą samą osobą, instytucją czy systemem"24. Jest to zatem zmiana, ale w ramach ciągłości. Wymaga ona, po pierwsze, identyfikacji problemu; po drugie, zaproponowania konkretnego rozwiązania, przy jednoczesnym zaprojektowaniu rozwiązań alternatywnych, to znaczy takich, które umożliwią odwołanie pierwotnych zmian, gdyby okazało się, że nie niosą one spodziewanego rezultatu; a po trzecie - zastosowania rozwiązań, które już się sprawdziły albo w mniejszej skali, albo w podobnym otoczeniu instytucjonalnym ${ }^{25}$. Jak widać, jest to stały schemat.

Jeśli przyjąć za Heywoodem, że „reforma to przyrastający postęp — nie dramatyczny wstrząs, stopniowa poprawa - nie radykalny zwrot, ewolucja - nie rewolucja"26, warto zastanowić się, czy działaniom przeprowadzonym jako reformy przez kolejne rządy w ramach polityki społecznej w Polsce od 1989 r. można przypisać cechy właściwe reformie.

Podstawę weryfikacji realnego socjalizmu stanowiły intelektualna i polityczna krytyka. W obszarze polityki społecznej pierwsze reformy faktycznie oznaczały „robienie czegoś nowego". Zmiana systemowa stanowiła przecież zaprzeczenie także dotychczasowej polityki społecznej państwa, którą trzeba było przemyśleć od nowa, biorąc pod uwagę nową jakość funkcjonowania rzeczywistości społecznej, role i kondycję państwa, aktywność i współdziałanie podmiotów innych niż państwo. W tym sensie były to reformy o charakterze adaptacyjnym, gdyż miały na celu przystosowanie systemu politycznego i jego instytucji do otoczenia. Trzeba uściślić jednak, że reformy wprowadzane były jeszcze przed tym, zanim na dobre rozpoczęła się w Polsce transformacja ustrojowa. W efekcie przyspieszyły one tylko upadek poprzedniego systemu, udowadniając niedostatki gospodarki centralnie planowanej. Ustawa z 23 grudnia 1988 r. o działalności gospodarczej (tzw. ustawa Wilczka) zalegalizowała np. prywatną działalność gospodarczą zgodnie z duchem laissez faire i laissez passer („co nie jest zakazane, jest dozwolone” i „pozwólcie działać”). Chodziło o zupełnie nowe, odmienne od dotychczasowych zasady organizujące gospodarkę oraz życie społeczne. Późniejsze reformy wynikały z konieczności wyboru modelu funkcjonowania państwa w nowej rzeczywistości politycznej, gospodarczej i społecznej.

${ }^{23}$ Reforma (fr. réforme, łac. reformatio) to przekształcenie; przedrostek re- w złożeniach oznacza: znów, na nowo, powtórnie, w tył, w przeciwnym kierunku. Zob. W. Kopaliński, Słownik wyrazów obcych i zwrotów obcojęzycznych, wydanie internetowe: http://www.slownik-online.pl/kopalinski/r.php (dostęp: 27 marca 2017).

24 A. Heywood, op. cit., s. 340.

25 P. Murrell, Conservative Political Philosophy and the Strategy of Economic Transition, s. 9, http://www. econweb.umd.edu/ murrell/articles/Conservative\%20Political\%20Philosophy.pdf. (dostęp: 18 marca 2017).

26 A. Heywood, op. cit., s. 341. 
Jak pisał w ostatniej książce Tadeusz Kowalik,

patrząc na Porozumienia Okrągłego Stołu z punktu widzenia analizy porównawczej systemów ekonomicznych, wyróżnić w nich można dwie koncepcje. Pierwsza to wprowadzenie gospodarki opartej na zasadach kooperacyjnych, socjaldemokratycznych, zapowiadających gospodarkę mieszaną, z dużą partycypacją pracowniczą i z polityką pełnego zatrudnienia [...]. Druga to postawienie na prywatyzację w postaci spółek akcyjnych, otwartą konkurencję światową, giełdyzację $[\ldots]^{27}$.

W pierwszej akcentowano ochronę praw pracowniczych i poziom życia, czym zbliżała się ona koncepcyjnie do ładu skandynawskiego. Druga natomiast oznaczała ograniczanie socjalnej funkcji państwa. Próba zastosowania rozwiązań dokładnie takich, jakie stosowano w krajach zachodnich, naznaczona była ryzykiem. Nałożyło się na to wiele czynników. Po pierwsze, transformacja w Polsce zbiegła się w czasie z kolejnym, trzecim etapem globalizacji na Zachodzie. Rozwój postępu naukowego i technologicznego, zwłaszcza w dziedzinie informatyki, który stanowi wyznacznik tego etapu, miał wpływ na organizację pracy i zarządzania, przyczyniając się jednocześnie do zupełnie odmiennego niż dotychczas sposobu wytwarzania i dystrybucji dóbr i usług. Polska na początku lat 90. nie była na to gotowa. Po drugie, ważne było zaplecze naukowe. Zarówno jedna, jak i druga wspomniana koncepcja wymagała wiedzy, którą posiadali nieliczni. Wszak, jeśli chodzi o ekonomię, jej wykładnia w tamtym okresie odnosiła się do zupełnie innej rzeczywistości. Ówczesne podręczniki do ekonomii dotyczyły przede wszystkim ekonomii socjalizmu. Po trzecie, ówczesne doświadczenie polegało na umiejętnym korzystaniu $\mathrm{z}$ wiedzy i przewidywaniu konsekwencji społecznych (słynna „niewidzialna ręka rynku" ${ }^{28}$ miała być panaceum na wszelkie niedogodności), a procedury demokratyczne, w których dochodzenie do konsensusu stanowi wartość nadrzędną, były jeszcze słabo rozwinięte. Dodać do tego należy ogólną sytuację gospodarczą, a przede wszystkim brak umiejętności komunikacyjnych. Społeczeństwo in gremio nie rozumiało - czemu trudno się dziwić - mechanizmów funkcjonowania gospodarki rynkowej. Politycy, ale także eksperci nie zawsze bowiem potrafili (potrafią) w przystępny sposób wytłumaczyć społeczeństwu całej złożoności mechanizmów gospodarczych, politycznych, a przede wszystkim przedstawić ich możliwych konsekwencji. Ponadto nie zawsze można odróżnić wypowiedzi polityczne ad hoc od teorii czy faktów.

Juliusz Gardawski w książce Polacy pracujący a kryzys fordyzmu, odnosząc się do reform wprowadzanych na początku lat 90. ubiegłego wieku, podnosi ważną kwestię dotyczącą możliwości wyboru modelu kapitalizmu przez polskie społeczeństwo w tamtym okresie. Konstatuje, że „wybór był bardzo ograniczony”. Mimo że w éxpose premiera Mazowieckiego akcent położony był na społeczną gospodarkę rynkową (tzw. kapitalizm koordynowany), to szybko Polska weszła na drogę kapitalizmu bez przymiotnika ${ }^{29}$.

27 T. Kowalik, www.Polskatransformacja.pl, Warszawa 2009, s. 50-51.

28 To sformułowanie przypisuje się Adamowi Smithowi, choć on sam zupełnie inaczej to ujął: „myśli tylko o swym własnym zarobku, a jednak w tym, jak i w wielu innych przypadkach, jakaś niewidzialna ręka kieruje nim tak, aby zdążał do celu, którego wcale nie zamierzał osiągnąć. Społeczeństwo zaś, które wcale w tym nie bierze udziału, nie zawsze na tym źle wychodzi” (Badania nad natura ludzka i przyczynami bogactwa narodów, t. 2, ks. V, Warszawa 2007, s. 40).

29 J. Gardawski, Polacy pracujacy a kryzys fordyzmu, Warszawa 2009, s. 61, 62. 
Wszystko to odbywało się z przekonaniem, że nie ma innej drogi. Plan Balcerowicza (tzw. szokowa terapia) był wynikiem „neofickiej wiary w wolny rynek głównych decydentów i ich doradców, która ułatwiła aplikację standardowej recepty Międzynarodowego Funduszu Walutowego, ignorującej odmienne warunki gospodarki wychodzącej z realnego socjalizmu"30. Ten przykład pokazuje dość dobrze, że choć idee nie są realne, to mają jak najbardziej realne konsekwencje. Wszystkie państwa tej części Europy, przechodząc transformację systemową, musiały dokonać reform. Najczęściej były to działania polegające na ograniczaniu wydatków socjalnych państwa. Okazało się jednak, że radykalne ograniczanie funkcji socjalnej państwa mogłoby przynieść skutki odwrotne od oczekiwanych. Dlatego konieczna stała się dogłębna reforma podstawowej instytucji polityki społecznej, jaką jest pomoc społeczna ${ }^{31}$. Gdyby nie zmiany, jakie wówczas wprowadzono, wiele osób - w tym bezrobotni - nie mieliby do niej prawa. W wyniku przeprowadzonych działań pomoc społeczna zaczęła przysługiwać zasadniczo wszystkim obywatelom w trudnej sytuacji życiowej. Za reformą pomocy społecznej przemawiały w tamtym czasie określone racje i idee, których dostarczyły nauki społeczne. Należą do nich np. uzasadnione obawy, że skrajna nędza i wykluczenie mogą być powodem niepokojów społecznych, a ład społeczny jest jedną z podstawowych wartości polityki społecznej. Reforma ta, a na dobrą sprawę stworzenie podstaw funkcjonowania pomocy społecznej od nowa, było gwarantem spójności społecznej.

Ważna stała się także reforma administracyjna, która polegała na ograniczeniu kontroli sprawowanej przez rząd na poziomie centralnym i przekazaniu części jego kompetencji innym podmiotom. Decentralizację wprowadzono w Polsce jako jedną z pierwszych i ważnych reform, jednak na początku nie było nawet jednoznacznego stanowiska co do liczby zdecentralizowanych szczebli władzy ${ }^{32}$. W 1992 r. dokonał się podział na dwa poziomy - centralny i gminy, a w 1999 doszły powiat i województwo. Argumentacja na rzecz decentralizacji jest przekonująca: wraz z przekazaniem przez państwo części uprawnień na podmioty niższego szczebla umacnia się m.in. pozycja obywateli, dokonuje się uczestnictwo polityczne we wspólnocie, decyzje stają się przejrzyste. Należy jednak pamiętać o tym, że aby decentralizacja odegrała swą pozytywną rolę, muszą być spełnione pewne warunki. I tak, nie można oczekiwać szybkich pozytywnych efektów, gdy zostaje ona wprowadzona odgórnie, bez uprzedniego przygotowania wszystkich uczestników, i polega na przeniesieniu trudności na poziomy niższe bez odpowiedniego wsparcia.

Apogeum reform przypadło na rok 1999. Cztery wielkie reformy społeczne wprowadzone przez rząd Jerzego Buzka obejmowały najważniejsze sfery życia społecznego: zdrowie publiczne, oświatę, system emerytalny i administrację. Można je uznać jednocześnie za takie, które dążyły zarówno do ulepszeń, jak i dogłębnej przemiany. Były one początkiem - można zaryzykować stwierdzenie - permanentnej reformy reform. Trudno od razu przewidzieć wszystkie skutki wprowadzanych reform, dlatego kolejny pakiet reform zwykle powstaje „niedługo po" i ma na celu wniesienie poprawek.

\footnotetext{
30 Ibidem, s. 62.

31 Ustawa z dnia 29 listopada 1990 r. o pomocy społecznej (Dz.U. $1990 \mathrm{Nr}$ 87, poz. 506).

32 Ustawa z dnia 8 marca 1990 r. o samorządzie terytorialnym (Dz.U. 1990 Nr 16, poz. 95).
} 
Przykłady oświaty i opieki zdrowotnej wskazują jednak na brak ciągłości: każdy rząd wprowadzał zmiany noszące znamiona małej rewolucji, a nie aprobaty dla status quo, wymagającego jedynie zmian, które pozwolą dostosować szkolnictwo czy opiekę zdrowotną do zmieniającej się rzeczywistości gospodarczej. Koalicja AWS w 1997 r. zdecentralizowała służbę zdrowia, powołując na wzór niemiecki kasy chorych. W 2004 r. SLD, realizując obietnice wyborcze, powołał Narodowy Fundusz Zdrowia. Obecnie ogłoszony został Narodowy Program Zdrowia Konstantego Radziwiłła, zapowiadający kolejne radykalne zmiany.

Podobne zawirowania przechodzi edukacja, która jest totalnie reformowana przez każdy kolejny rząd ${ }^{33}$. Jako przykład właściwego podejścia do edukacji może posłużyć Finlandia. Reformę rozpoczęto tam jeszcze w latach 70 . ubiegłego wieku ${ }^{34}$ i pewne zmiany, do czasów nam współczesnych, musiały zostać oczywiście wprowadzone. Nie polegają one jednak na rozpoczynaniu za każdym razem wszystkiego od nowa, ale na korygowaniu tego, co było konieczne ze względu na zmieniające się uwarunkowania. Jest zatem zasadnicza różnica między systemem edukacji w Finlandii i w Polsce, w której „przez ostatnich 25 lat wykształciła się kultura reformowania opartego na nieustannym zmienianiu prawa oświatowego, co spowodowało jego przeformalizowanie, a także ubezwłasnowolniło w wielu obszarach liderów w polskiej oświacie" ${ }^{35}$.

Przedstawiciele nauk społecznych każdorazowo są w stanie dostarczyć odpowiednich ekspertyz, danych statystycznych, opracowań, które uwiarygodnią i uzasadnią konieczność wprowadzania określonych zmian, często przeciwstawnych wobec siebie. W konsekwencji istnieje ryzyko, że zastosowane zostanie rozwiązanie, które odpowiada potrzebom chwili w krótkiej perspektywie czasowej wyznaczanej przez kalendarz wyborczy, a nie takie, którego pozytywne efekty będą odczuwalne, jednak dopiero w przyszłości. James G. March i Johan P. Olsen stwierdzają: „Doświadczenia związane z reformami instytucjonalnymi wskazują, że pomyślna reforma kompleksowa może zależeć od wydłużania horyzontów czasowych działań reformatorskich oraz od ochrony przed krótkotrwałymi fluktuacjami uwagi" ${ }^{36}$. Odejście od takiego podejścia może stanowić pułapkę ideologicznego charakteru polityki społecznej, ale też jest potwierdzeniem, że wspomniany typ stanowiska $w$ relacjach między światem nauki i polityki, polegający na bezwarunkowym poparciu badaczy wobec władzy, nie należy do przeszłości.

Warto zwrócić uwagę na jeszcze jedną ważną sprawę przy okazji dyskusji na temat reform społecznych. Chodzi o ich akceptację, co łączy się ze społecznym zrozumieniem konieczności ich przeprowadzenia, a także o to, w jaki sposób są one wyjaśniane (czy w ogóle są). Rząd jest motorem zmiany, działającym poprzez instytucje państwo$\mathrm{we}^{37}$. Pozytywny odbiór decyzji politycznych, a zatem i samych reform, jest więc w du-

$33 \mathrm{~W}$ odniesieniu do szkolnictwa pojawiło się ostatnio pojęcie deformy, oznaczające psucie, a nie naprawianie.

34 Zob. W. Walkowska, O edukacji w Finlandii, http://otokoclub.pl/temat_,60,o-edukacji-w-finlandii. html (dostęp: 10 marca 2017).

35 J. Fazlagić, Specyfika fińskiego systemu edukacji na tle Polski, „E-mentor” 59, 2015, nr 2, http://www.e-mentor.edu.pl/artykul/index/numer/59/id/1164 (dostęp: 10 marca 2017).

36 J.G. March, J.P. Olsen, Instytucje. Organizacyjne podstawy polityki, Warszawa 2005, s. 124.

37 T. Beton, I. Craib, op. cit., s. 61. 
żym stopniu uzależniony od stopnia zaufania społeczeństwa do władzy. W badaniach z 2015 r. poziom zaufania do rządu kształtował się na poziomie $40 \%$, a do sejmu $-41 \%$. Nie jest to wynik, który można uznać za zadowalający ${ }^{38}$.

Przyczyną braku społecznej akceptacji dla reform może być także fundamentalna niemożliwość zrozumienia konieczności ich wdrażania. Wymaga to bowiem wiedzy, przynajmniej na podstawowym poziomie, o mechanizmach funkcjonowania rynku, państwa i społeczeństwa. Edukowanie w tym zakresie powinno być domeną przedstawicieli nauk społecznych.

\section{Podsumowanie}

Podstawowym czynnikiem mogącym przyczynić się do powodzenia reform są połączone siły reprezentowane przez nauki społeczne, świat polityki i społeczeństwo.

Sytuacja społeczna (niekorzystne procesy demograficzne), gospodarcza (niepewna sytuacja na rynku pracy) i polityczna (globalizacja) powodują, że reformy polityki społecznej na poziomach krajowych utożsamiane są przez większość jej adresatów z kompensacją ograniczeń. Obawy przed redukcją świadczeń i podział społeczeństwa na tych, którzy korzystają z polityki społecznej, i na tych, którzy na nią dają, nie sprzyjają przeprowadzeniu reform. Decyzje polityczne, a reforma jest taką decyzją, pociągają za sobą określone skutki - te zakładane i te niezamierzone, niechciane. Oba rodzaje skutków warto uwzględnić. Wiele zależy zatem od tego, jak konieczność reformy zostanie przedstawiona i uzasadniona. Problemy społeczne mogą zostać wyjaśnione i zinterpretowane dzięki wiedzy naukowej. Przedstawiciele nauk społecznych posiadają wiedzę na temat rozmaitych aspektów życia społecznego, takich jak bezrobocie, aspiracje edukacyjne, wzorce zawierania małżeństw, przestępczości, wzorce konsumpcyjne, postaw i wartości itp., która może z powodzeniem zostać przełożona na konkretne działania polityczne.

\section{Bibliografia}

Becker G.S., Crime and punishment: An economic approach, www.nber.org/chapters/c3625.pdf (dostęp: 23 października 2017).

Beton T., Craib I., Filozofia nauk społecznych, Wydawnictwo Dolnośląskiej Szkoły Wyższej Edukacji TWP, Wrocław 2003.

Diagnoza społeczna 2015. Warunki i jakość życia Polaków. Raport, red. J. Czapiński, T. Panek, Rada Monitoringu Społecznego, Warszawa 2015.

Dilthey W., Budowa świata historycznego w naukach humanistycznych, Wydawnictwo słowo/obraz terytoria, Gdańsk 2005.

Fazlagić J., Specyfika fińskiego systemu edukacji na tle Polski, „E-mentor” 59, 2015, nr 2, http://www.e-mentor.edu.pl/artykul/index/numer/59/id/1164 (dostęp: 10 marca 2017).

Gardawski J., Polacy pracujący a kryzys fordyzmu, Wydawnictwo Naukowe Scholar, Warszawa 2009.

38 Diagnoza społeczna 2015. Warunki i jakość życia Polaków. Raport, red. J. Czapiński, T. Panek, Warszawa 2015, s. 88. 
Grobler A., Metodologia nauk, Wydawnictwo Areus — Wydawnictwo Znak, Kraków 2006.

Heywood A., Teoria polityki. Wprowadzenie, PWN, Warszawa 2009.

Keynes J.M., Ogólna teoria zatrudnienia, procentu i pieniądza, PWN, Warszawa 2003.

Kiersztyn A., Czy bieda czyni złodzieja? Związki między bezrobociem, ubóstwem a przestępczościa, Wydawnictwo UW, Warszawa 2008.

Klementewicz T., Kompradorzy znad Wisty, „Le Monde diplomatique” nr 134, 2017, http://monde-diplomatique.pl/LMD134/index.php?id=4_2 (dostęp: 3 lipca 2017).

Kopaliński W., Słownik wyrazów obcych i zwrotów obcojęzycznych, wydanie internetowe: http://www. slownik-online.pl/kopalinski/r.php (dostęp: 27 marca 2017).

Kowalik T., www.Polskatransformacja.pl, Warszawskie Wydawnictwo Muza SA, Warszawa 2009.

Malewski M., Teorie andragogiczne - metodologia teoretyczności dyscypliny naukowej, Wydawnictwo Uniwersytetu Wrocławskiego, Wrocław 1998.

March J.G., Olsen J.P., Instytucje. Organizacyjne podstawy polityki, Wydawnictwo Naukowe Scholar, Warszawa 2005.

Markiewicz W., Morawski W., The Influence of Social Sciences on Political Decisions in Poland, [w:] Social Sciences and Modern States: National Experiences and Theoretical Crossroads, red. P. Wagner et al., Cambridge University Press, Cambridge 1991.

Murrell P., Conservative Political Philosophy and the Strategy of Economic Transition, s. 9, http://www.econweb.umd.edu/ murrell/articles/Conservative\%20Political\%20Philosophy.pdf. (dostęp: 18 marca 2017).

Rozporządzenie Ministra Nauki i Szkolnictwa Wyższego z 8 sierpnia 2011 r. w sprawie obszarów wiedzy, dziedzin nauki i sztuki oraz dyscyplin naukowych i artystycznych, Dz.U. z dnia 30 sierpnia 2011 r.

Słownik socjologii i nauk społecznych, red. G. Marshall, red. naukowa wyd. polskiego M. Tabin, PWN, Warszawa 2005.

Smith A., Badania nad naturą ludzką i przyczynami bogactwa narodów, t. 2, ks. V, PWN, Warszawa 2007.

Ustawa z dnia 8 marca 1990 r. o samorządzie terytorialnym, Dz.U. $1990 \mathrm{Nr}$ 16, poz. 95.

Ustawa z dnia 29 listopada 1990 r. o pomocy społecznej, Dz.U. 1990 Nr 87, poz. 506.

Walkowska W., O edukacji w Finlandii, http://otokoclub.pl/temat_60,o-edukacji-w-finlandii.html (dostęp: 10 kwietnia 2017).

Wallerstein I., Analiza systemów-światów. Wprowadzenie, Wydawnictwo Akademickie „Dialog”, Warszawa 2007.

Weber M., Gospodarka społeczna, t. 1. Kategorie socjologiczne, PWN, Warszawa 2002.

\section{The role of social sciences in the projects of programs and social reforms}

Keywords: social sciences, the rights of social sciences, social policy, reform

\section{Summary}

The subject of the article is the problem with applying social science knowledge to programs and projects of social reforms. Two aspects of the issue have been pointed out. The first refers to the role of social sciences as an intellectual backdrop for social reform programs, while the other shows the consequences of a specific definition of reform and assigning it a high (or not) position in the scale value of social activities and the practice of its implementation. The question arises about the nature of reforms in Poland, from the 1990s to the present. In three interrelated parts, the origins and development of social sciences have been presented, answering the question of how to support social policy with social science knowledge as useful knowledge, and a reference to social reforms in Poland after 1989 has been made. The article ends with a conclusion that the potential success of the reforms is affected by the cooperation between social sciences, the world of politics and society. 